This is an Accepted Manuscript of an article published by Taylor \& Francis in Environmental Politics on 14 December 2017, available online:

\title{
https://www.tandfonline.com/doi/abs/10.1080/09644016.2018.1414745
}

\section{Chronicle of a Death Foretold: The Green Party of Aotearoa New Zealand and the 2017 Election}

In the run-up to the 2017 General Election, the Green Party of Aotearoa New Zealand appeared to be in an excellent position to capitalise on earlier success and grow further. The departure of Prime Minister John Key in December 2016 had left the governing National Party weakened, while the ongoing poor performance of the Labour Party in opinion polls created fertile ground for the Green Party. The steady electoral growth of the Green Party had made it one of the most electorally successful green parties in the world, one of the few to exceed $10 \%$ of the national vote (see Table 1). However, events during the campaign left the party facing the real prospect of disappearing from Parliament altogether. Despite losing votes and seats, the eventual outcome of the election gave them the most influence and power in their history as an independent party.

\section{The Campaign}

The Green Party entered the 2017 election campaign from a position of relative strength. As shown in Table 1 below and described in O'Brien (2013), recent elections had seen the Green Party capitalise on public dissatisfaction with the New Zealand Labour Party (the 'main' opposition party). They were able to expand their vote to breakthrough as a 'medium' rather than minor party, consistently polling over $10 \%$ and as high as 13\% since early 2015 (see Figure 1). In the face of Labour's ongoing difficulties and the lack of other competitors for progressive votes, they were able to present themselves as a credible third force, effectively challenging the governing National Party. This transition had been accompanied by a stable message that associated action on environmental issues with broader areas of social justice and economic performance, their 2014 manifesto being framed around three messages or strands: "Cleaner environment", "Fairer society" and "Smarter economy".

Table 1 - Green and Labour Party Vote and Seats (1999-2014)

\begin{tabular}{|c|c|c|c|c|}
\hline Year & $\begin{array}{c}\text { Green } \\
\text { Vote \% }\end{array}$ & $\begin{array}{c}\text { Green } \\
\text { Seats }\end{array}$ & $\begin{array}{c}\text { Labour } \\
\text { Vote \% }\end{array}$ & $\begin{array}{c}\text { Labour } \\
\text { Seats }\end{array}$ \\
\hline 1999 & 5.2 & 7 & 38.7 & 49 \\
\hline 2002 & 7.0 & 9 & 41.3 & 52 \\
\hline 2005 & 5.1 & 6 & 41.1 & 50 \\
\hline 2008 & 6.2 & 9 & 34.0 & 43 \\
\hline 2011 & 11.1 & 14 & 27.5 & 34 \\
\hline 2014 & 10.7 & 14 & 25.1 & 32 \\
\hline
\end{tabular}

Source: New Zealand Electoral Commission, available at www.elections.org.nz [accessed 4 September 2017] 
This is an Accepted Manuscript of an article published by Taylor \& Francis in Environmental Politics on 14 December 2017, available online:

\section{https://www.tandfonline.com/doi/abs/10.1080/09644016.2018.1414745}

A critical turning point came at the AGM and campaign launch in July 2017. Highlighting the need for social welfare reform, Green co-leader Metiria Turei revealed that she had committed minor social welfare fraud as a solo parent in the 1990s. Intended to highlight the difficulties associated with surviving in poverty, this initially appeared to have had little negative effect on the Green Party. Two subsequent opinion polls showed Green support increasing slightly in one and significantly in the other (from $11 \%$ to $15 \%$ ), with support for Labour continuing to decline. This led one former Green MP to claim that the Party was now attracting Labour's core supporters and was on track to grow even further (RNZ National 2017).

However, over the subsequent weeks, additional concerns began to emerge regarding Turei's past behaviour, including further questions about her financial status while receiving social support and her confession that in the early 1980s she had falsified her address on the electoral roll. The ongoing furore appeared to undermine the Party's efforts to build a reputation for fiscal credibility and realism, particularly after two sitting Green MPs chose to resign their candidacies citing ethical concerns over Turei's behaviour. In early August Turei resigned both the co-leadership and her place on the Party's electoral list. Weakened by this controversy, the party was less able to respond to the next major development in the campaign: the resurgence of the Labour Party.

The Labour Party's vote share had remained low during the initial phase of the campaign. Labour leader Andrew Little initially vowed to remain in place, but the party then decided to gamble on changing its leader less than two months out from election day. He was replaced by Jacinda Ardern, who at 37 became the youngest leader of a major party in modern New Zealand history. The accession of a new, charismatic leader paid off dramatically, with Labour's polling - which in most sources had not been above $30 \%$ since late 2015 - immediately surging to the high 30 s. In several polls over the next few weeks, Labour gained a higher share than the National Party - something it had not achieved in over 10 years.

Figure 1 - Poll of Polls (2015-2017) 


\section{https://www.tandfonline.com/doi/abs/10.1080/09644016.2018.1414745}

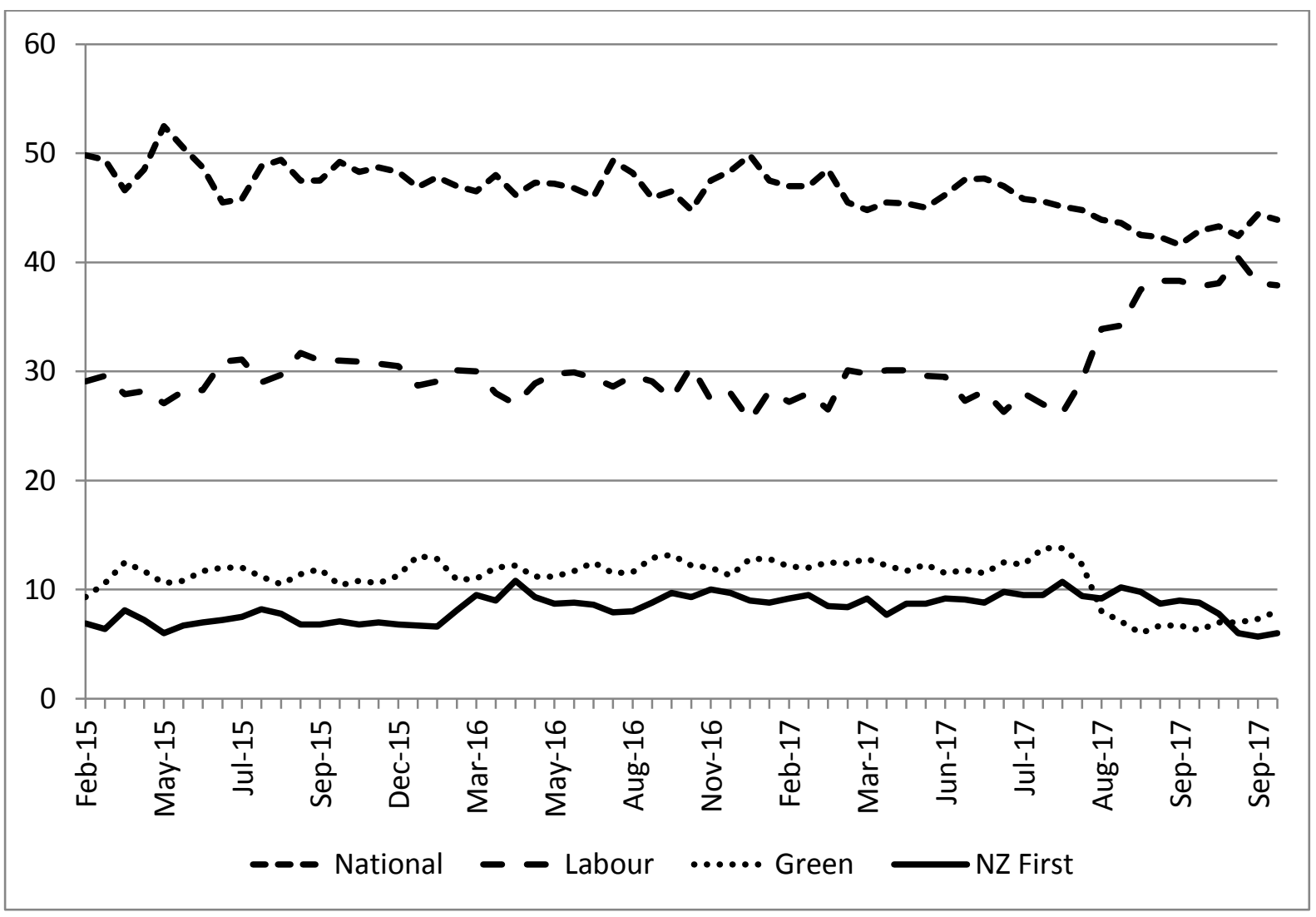

Source: Fyers, 2017.

This phenomenon, commonly labelled 'Jacindamania' by the media, should have been positive for the Green Party. While they did not explicitly campaign together, the Greens and Labour had been making conscious efforts to present themselves as a joint government-in-waiting, including signing a formal Memorandum of Understanding regarding their relationship and releasing joint Budget Responsibility Rules that would govern their fiscal planning if in government. Labour's sudden recovery made the prospect of such a progressive government a real possibility, rather than the outside chance it had appeared to be only months earlier.

The Labour resurgence demonstrated, however, the existence of a clear inverse relationship between the two parties, as the surge was accompanied by a plunge in Green Party support. Although initially both the National Party and the conservative New Zealand First Party (the other 'medium' party in the political landscape) saw falls, these were relatively small. In comparison, the first polls following Jacinda Ardern's accession showed large declines in Green support: from $13 \%$ to $8 \%$ in one and from $15 \%$ to $4.3 \%$ in the other (reflected in Figure 1). Moreover, not only was support for the Labour and National parties now at similar levels, but Ardern represented a clear break and contrast with the previous leadership of both parties, and particularly with the National Party leader. 
This is an Accepted Manuscript of an article published by Taylor \& Francis in Environmental Politics on 14 December 2017, available online:

\section{https://www.tandfonline.com/doi/abs/10.1080/09644016.2018.1414745}

The electoral narrative around the Green Party thus quickly transformed into one of survival. Crucially, the latter poll indicated that the Greens were in danger of falling below the $5 \%$ threshold for representation under New Zealand's MMP electoral system; with no constituency seats to rely on, the Green Party was reliant on meeting this threshold to retain its presence in parliament. With polls during the remainder of the campaign putting the Greens between $5 \%$ and $7 \%$, this threat of disappearing from parliament loomed large, exacerbated by a past tendency for the Green Party's actual vote share to be slightly lower than its polling.

During the campaign, then, the Greens effectively faced a 'perfect storm' of factors. Weakened by the controversy around Turei's announcement, the party found difficulty in responding to the challenge of a resurgent Labour. A significant part of Labour's polling surge appeared to be based on a new leader more able to reconnect with voters who had seen the Greens as a viable alternative. This leader also proved appealing for the media, whose coverage of the election campaign reverted to a more traditional focus on the two-party fight between Labour and National, arguably encouraging the public to concentrate on which of those two parties they would support and neglect consideration of others beyond their role as supports for the two main players.

\section{Election Outcome and Future Prospects}

Although the Greens did exceed the threshold, gaining an additional seat following the count of special votes, the election result reflected the uncertainty that had characterised the latter part of the campaign. The National Party emerged as the largest party (Table 2) by a clear margin but saw its vote share decline (falling short of achieving a majority), with Labour's improved vote share reducing the minor party vote share. The Māori Party and United Future Party both disappeared, while the ACT Party survived with a single seat. The New Zealand First Party overtook the Green Party to come third, but with a reduced share of the vote.

Table 2 -New Zealand General Election Results - 2014 and 2017

\begin{tabular}{|l|c|c|c|c|c|c|c|c|}
\hline & \multicolumn{4}{|c|}{2014} & \multicolumn{4}{c|}{2017} \\
\hline & $\begin{array}{c}\text { Party } \\
\text { Votes }\end{array}$ & $\begin{array}{c}\text { Vote } \\
\%\end{array}$ & $\begin{array}{c}\text { Electorate } \\
\text { Seats }\end{array}$ & $\begin{array}{c}\text { List } \\
\text { Seats }\end{array}$ & $\begin{array}{c}\text { Party } \\
\text { Votes }\end{array}$ & $\begin{array}{c}\text { Vote } \\
\%\end{array}$ & $\begin{array}{c}\text { Electorate } \\
\text { Seats }\end{array}$ & $\begin{array}{c}\text { List } \\
\text { Seats }\end{array}$ \\
\hline $\begin{array}{l}\text { National } \\
\text { Party }\end{array}$ & $1,131,501$ & 47.0 & 41 & 19 & $1,152,075$ & 44.4 & 41 & 15 \\
\hline $\begin{array}{l}\text { Labour } \\
\text { Party }\end{array}$ & 604,535 & 25.1 & 27 & 5 & 956,184 & 36.9 & 29 & 17 \\
\hline $\begin{array}{l}\text { New } \\
\text { Zealand } \\
\text { First Party }\end{array}$ & 208,300 & 8.7 & 0 & 11 & 186,706 & 7.2 & - & 9 \\
\hline Green Party & 257,359 & 10.7 & 0 & 14 & 162,443 & 6.3 & - & 8 \\
\hline
\end{tabular}


This is an Accepted Manuscript of an article published by Taylor \& Francis in Environmental Politics on 14 December 2017, available online:

\section{https://www.tandfonline.com/doi/abs/10.1080/09644016.2018.1414745}

\begin{tabular}{|l|c|c|c|c|c|c|c|c|}
\hline $\begin{array}{l}\text { ACT New } \\
\text { Zealand }\end{array}$ & 16,689 & 0.7 & 1 & 0 & 13,075 & 0.5 & 1 & - \\
\hline Māori Party & 31,849 & 1.3 & 1 & 1 & 30,580 & 1.2 & & \\
\hline $\begin{array}{l}\text { United } \\
\text { Future }\end{array}$ & 5,286 & 0.2 & 1 & 0 & 1,782 & 0.1 & & \\
\hline $\begin{array}{l}\text { Minor } \\
\text { Parties }\end{array}$ & 150,103 & 6.2 & & & 89,051 & 4.7 & - & - \\
\hline Total & $2,405,622$ & & 71 & 50 & $2,591,896$ & & 71 & 49 \\
\hline
\end{tabular}

Source: New Zealand Electoral Commission, available at www.elections.org.nz [accessed 18 October 2017]

In this landscape, the outcome of the election was not immediately apparent; the two main possibilities were a National-New Zealand First Coalition government, or a Labour-New Zealand FirstGreen arrangement. The previously-stated willingness of New Zealand First to negotiate with either major party led to its leader, Winston Peters, becoming 'kingmaker' for the third time since MMP was introduced in 1996.

Labour immediately began negotiating with the Greens to establish the grounds for their involvement in any arrangement with New Zealand First. The Green Party's situation therefore rapidly switched from fighting for survival, to having government seriously within their grasp for the first time in their history. Some right-wing commentators publicly encouraged the Greens to break their alliance with Labour and consider a 'Teal Coalition' with National, although this was never a realistic prospect given a large range of significant practical issues and policy differences and it is questionable to what extent these commentators were serious about the possibility (see for example Small, 2017). After three weeks of negotiations, Peters publicly confirmed that New Zealand First had chosen to support the Labour Party, and it was announced that the next government would consist of a Labour-New Zealand First coalition, with the Greens offering confidence and supply in return for specific policy agreements and several ministerial positions.

The Labour-led administration that resulted from negotiations is a positive outcome for the Green Party that arguably represents the best of both worlds. In exchange for their support, the Green Party was able to secure Ministerial roles outside Cabinet, and progress several specific goals. Party leader James Shaw serves as Minister for Climate Change and Statistics, with Julie Anne Genter becoming Minister for Women and Eugenie Sage Minister for Conservation and for Land Information. At the same time, their position formally outside government may allow the party to distance itself from unpopular decisions made by the administration and their agreement explicitly allows them to criticise the government on areas not related to their ministerial portfolios. Thus, 
This is an Accepted Manuscript of an article published by Taylor \& Francis in Environmental Politics on 14 December 2017, available online:

\section{https://www.tandfonline.com/doi/abs/10.1080/09644016.2018.1414745}

ironically, their poorest electoral result in several years has led to a situation where they may have more influence and a heightened chance of achieving their policy aims than at any other point in their history.

Fundamentally, though, the election result highlighted the challenge that the Green Party faces in breaking free from their minor party status. Winning eight seats was a creditable result, but also a dramatic reversal from the gains of the previous two elections. The recovery of Labour attracted large parts of their vote away and undermined attempts to broaden their appeal by targeting issues such as welfare and economic performance. Although the Greens were seen as a credible alternative to Labour by progressive voters, they were still seen as an alternative. The core Green vote share, of those who support the Party in its own right remains in the $5-7 \%$ band that it secured in the 19992005 elections. This is above the threshold required for representation in Parliament, but is a base that remains stubbornly low.

\section{References:}

Fyers, A. (2017) 'Stuff Poll of Polls: Election Result Too Close to Call', Stuff https://www.stuff.co.nz/national/politics/97128177 [accessed 26 September 2017]

New Zealand Electoral Commission, available at www.elections.org.nz [accessed 18 October 2017]

O'Brien, T. (2013) 'Leaving the Minors: The Green Party of Aotearoa New Zealand and the 2011 General Election', Representation, 49(1): 69-81.

RNZ National. (2017). 'A 'disgraceful stand by Jacinda to undermine Metiria' - Sue Bradford'. RNZ. http://www.radionz.co.nz/national/programmes/morningreport/audio/201853920/a-disgracefulstand-by-jacinda-to-undermine-metiria-sue-bradford [accessed 28 October 2017]

Small, V. (2017). 'No, honestly, National really did seem to be serious about a coalition with the Greens'.

https://www.stuff.co.nz/national/politics/opinion/97529017/no-honestly-national-really-did-seemto-be-serious-about-a-coalition-with-the-greens [accessed 28 October 2017]

Thomas O'Brien

Centre for International Security and Resilience Cranfield University at the Defence Academy of the United Kingdom

t.obrien@cranfield.ac.uk

Nicholas Huntington

School of Government

Victoria University Wellington

huntinnyk@myvuw.ac.nz 